\title{
Designing culturally-rich local games for mathematics learning
}

\author{
Elly Susanti ${ }^{1}$, Nur Wiji Sholikin ${ }^{1}$, Marhayati ${ }^{1}$, Turmudi ${ }^{1}$
}

\begin{abstract}
Abstrak: Penelitian ini bertujuan merancang dan mengujicoba pembelajaran matematika berbasis permainan tradisional (das-dasan) sebagai upaya untuk mengembangkan kompetensi strategis matematis siswa. Penelitian ini terdiri dari tiga tahap, yaitu: identifikasi dan analisis permainan tradisional, perancangan pembelajaran berbasis permainan tradisional berdasarkan Realistic Mathematics Education (RME), dan implementasi dalam pembelajaran di kelas yang melibatkan 20 siswa kelas 7. Data terkait permainan tradisional dikumpulkan melalui pengamatan dan wawancara dengan lima warga tempat permainan tersebut berasal. Data kemampuan strategis matematis siswa diperoleh melalui tes yang diberikan setelah pembelajaran. Analisis hasil tes siswa merujuk pada indikator kompetensi strategis matematis siswa. Hasil penelitian menunjukkan 15 siswa berhasil memenuhi semua indikator kompetensi strategis matematis dengan kategori nilai akhir sangat baik. Sedangkan 5 siswa berhasil mencapai indikator pertama (merumuskan masalah) namun belum semua memenuhi indikator merepresentasikan dan menyelesaikan masalah. Temuan penelitian ini menunjukkan bahwa pembelajaran matematika berbasis permainan tradisional das-dasan memiliki potensi untuk membantu siswa mengembangkan kemampuan strategis matematis.
\end{abstract}

Kata kunci: Rancangan pembelajaran, Etnomatematika, Permainan tradisional, Das-dasan, RME

\begin{abstract}
This study aimed to design and implement local games-based mathematics learning (dasdasan) to support students' mathematical strategic competence. It consisted of three stages, namely the identification and analysis of the traditional game, the design of learning activities based on Realistic Mathematics Education (RME), and the implementation in the classroom which involved twenty $7^{\text {th }}$-grade students. Data about the local game was collected through observations and interviews with five residents where the game is originated. Data on students' strategic competence was achieved through a test given to the students after learning. The analysis of test results refers to the indicators of strategic competence. The present study found that fifteen students are able to achieve all indicators (formulating, representing, and solving the problems) with high scores. Meanwhile, five students could only represent the problems but have not fulfilled the last two indicators. The findings of this study indicate that learning mathematics based on traditional dasdasan games has the potential to help students develop strategic competence.
\end{abstract}

Keywords: Learning design, Ethnomathematics, Local game, Das-dasan, RME

\section{A. Introduction}

Ethnomathematics is a culture-oriented learning study and has the objective to explore mathematical concepts in the socio-cultural activities of the community (Rosa \& Orey, 2011; Tereshkina et al., 2015). The culture can be in the form of language, dance, games, traditional houses, and various types of regular community activities that can be linked to mathematics

\footnotetext{
${ }^{1}$ Department of Mathematics Education, Universitas Islam Negeri Maulana Malik Ibrahim Malang, Jln. Gajayana 50 Malang 65144, ellysusanti@mat.uin-malang.ac.id
} 
learning so that it has a significant role in developing students' mathematical abilities (Andersonpence, 2015; Ismail \& Ismail, 2010; Maryati \& Pratiwi, 2019; Nofrianto, 2015; Risdiyanti \& Prahmana, 2018). Mathematics learning integrated with community culture promote students' abilities in exploring mathematical concepts (Brandt \& Chernoff, 2015; Saldanha, Kroetz, \& de Lara, 2016; Rosa \& Orey, 2017). Indeed, community culture can be utilized to support students in learning mathematics, one of which is a traditional game.

Prior studies (Riberio, Palhares, \& Salinas, 2020; Nkopodi \& Mosimege, 2009; Tatira, Mutambara, \& Chagwiza, 2012) found that students could actively participate in learning using traditional games to construct new knowledge by linking acquired knowledge with prior experiences. Moreover, learning with traditional games can develop students' imagination and creativity in thinking to understand mathematical concepts independently, such as geometric shapes, patterns, and line positions (Bandeira, 2017; Fouze \& Amit, 2018; Zaenuri, Teguh, \& Dwidayati, 2017). From these results, it can be concluded that learning mathematics with traditional games makes learning more meaningful and effective.

Considering the didactic aspect of traditional games in mathematics learning, the present study developed local game-based mathematics learning. The local games, called das-dasan, is one of the traditional games in Indonesia which has didactic potential to support students learn geometry. The tenets of RME (Gravemeijer, 1994): the use of the real-world context in learning, the use of models, students' contributions in learning, learning activities take place interactively, and linkages between learning topics were used can encourage students to learn geometry. A number of studies (Gravemeijer \& van Eerde, 2009; Palupi \& Khabibah, 2018; Shandy, 2017; Sitorus \& Masrayati, 2016; Yuniati \& Sari, 2018) have shown that RME help students link mathematical concepts with real-world contexts and rediscover geometry ideas and concepts independently through students' exploration.

Several studies (e.g., Helsa \& Hartono, 2011; Jaelani, Putri, \& Hartono, 2013; Nursyahidah, Putri, \& Somakim, 2013) used RME with traditional games to support students learn varied topics. Jaelani et al. (2013) utilized traditional gasing game to help students' reinvention of time measurement historically. In the other context, Nasrullah and Zulkardi (2011) foster students' understanding of counting using a local game called Bermain Satu Rumah. Also, Nursyahidah et al. (2013) developed learning activities to promote students' understanding of addition up to 20 using Dakocan game. The present study is similar to the studies above regarding the use of RME but employ different traditional games to develop students' mathematical strategic competence in rectangle and triangle topic. We argue that different traditional games which have didactical functions should be promoted and used in mathematics learning. Besides targeting the effectivity of instructional practices, it also preserved the traditional games amid the massive emergence of digital games.

The present study aimed to develop students' mathematical strategic competence using the designed traditional games-based mathematics learning. Mathematical strategic competence is students' ability to formulate, represent, and solve mathematical problems. It is not different with problem-solving and problem formulation, which are commonly known in the literature of mathematics education (Kilpatrick, Swafford, \& Findell, 2001). Strategic competence is one of the strands of mathematical proficiency developed for a large scale research project involving students from pre-kindergarten to grade 8 . This competence is pivotal for students when they might find situations outside of school, which are needed to be formulated and solved using mathematics. 


\section{B. Methods}

The present study followed three stages: the local game identification/analysis stage, the step of designing local game-based learning, and the implementation phase in classroom learning.

\section{Local game identification and analysis stage}

The first stage aimed to find out the history of the traditional game, called das-dasan, the steps of the game, and the possible implementation in mathematics learning. We observed the game and interviewed five residents in Gebang sub-village, Sukorame village, Sukorame subdistrict, Lamongan regency, Indonesia. The place is considered as the origin place of the game. The interviews were recorded to be further analysed and compared with other available resources of the history of the game.

\section{The stage of developing local game-based learning}

At this stage, we designed mathematics learning for $7^{\text {th }}$-grade students which consist of learning activities, learning tools, and the indicators of strategic competence.

\section{Learning activities}

Five tenets of RME (Gravemeijer, 1994) were used as a reference in preparing the learning activities (Table 1). The basic competence to be achieved in the learning is linking the circumference and area for various types of rectangles (rectangles, rhombus, parallelogram, trapezoid, and kite) and triangles. In addition to the basic competence, the learning goals are the students are (1) able to recognize and understand the types of rectangles and triangles, (2) able to name and find rectangles and triangles in the surrounding environment, and (3) able to solve the problems related to rectangle and triangle.

Table 1. The designed learning activities

\begin{tabular}{cll}
\hline No. & \multicolumn{1}{c}{ RME Tenets } & \multicolumn{1}{c}{ Learning steps } \\
\hline 1 & $\begin{array}{l}\text { The use of real-world } \\
\text { contexts in learning }\end{array}$ & $\begin{array}{l}\text { The teacher communicates the learning objectives and the } \\
\text { roles of the game. The students in a group are provided with } \\
\text { a worksheet which comprises mathematics tasks about } \\
\text { triangle and rectangle topics to be accomplished. The } \\
\text { mathematics tasks are deliberately linked with the game. }\end{array}$ \\
& & $\begin{array}{l}\text { Using the worksheet, students are encouraged to create } \\
\text { pictorial representations to help solve mathematics tasks. }\end{array}$ \\
2 & The use of models & $\begin{array}{l}\text { Students form groups of 4-5 member. } \\
\text { Students play the das-dasan game while observing and } \\
\text { laking notes on matters relating to the worksheet. }\end{array}$ \\
4 & $\begin{array}{l}\text { Interactive learning } \\
\text { activities }\end{array}$ & $\begin{array}{l}\text { Students in the group discussed the mathematical ideas in } \\
\text { the game to solve mathematics tasks in the worksheet; } \\
\text { following this, the whole-class discussion is also } \\
\text { administered. }\end{array}$ \\
& $\begin{array}{l}\text { Students determine the planes to solve the problems related } \\
\text { to daily life. }\end{array}$ \\
\hline
\end{tabular}




\section{Learning tools}

We designed the learning tools to support the learning activities: learning plans, a test to examine students' mathematical strategic competence, and students' worksheet, which comprise mathematics tasks. The detail of learning plans is not presented in this article, but it fully follows the designated learning activities (Table 1). The developed test to examine students' strategic competence is as follows.

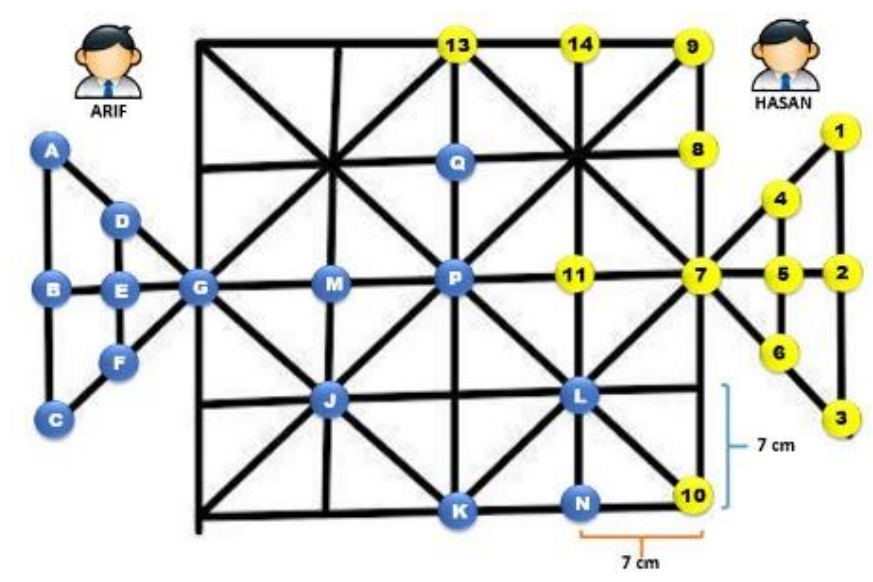

Arif and Hasan are playing das-dasan. The game gets exciting, uwong ${ }^{2}$ Arif and uwong Hasan eat each other. When the game goes fun, Arif forgets that uwong $(L)$ eats uwong (11), Arif runs uwong (Q) going forward, then Arif got hit with Das, and as his penalty, Hasan has the right to take Arif's three uwong. Hasan could eat Arif's more uwong, Hasan took uwong ( $P, G$, and $K)$. Next, Hasan runs uwong (10) eating uwong (L, $M, J$, and $N)$. So far, Hasan managed to get 7 Arif's uwong consisting of 3 fines and four eating results. Based on the das-dasan game played by Arif and Hasan.

a. What plane was formed by Hasan's uwong (10)?

b. Determine and evaluate the area formed by uwong (10)!

c. In the das-dasan game arena, make a minimum of 3 different rectangular ways which has the same area as the plane formed by uwong (10).

In the students' worksheet, we developed mathematics tasks to solve by the students in the group. The tasks are to (1) draw the rectangles and triangles formed in the das-dasan game arena, (2) list as many as rectangles and triangles found in the das-dasan game arena, and (3) formulate steps to get the number of rectangles and triangles on the das-dasan game arena.

\section{The indicators of mathematics strategic competence}

Three aspects representing the seven indicators of strategic competence (Kilpatrick et al., 2001) were coded (Table 2). It was used as a reference to determine the development of students' mathematical strategic competence. The three aspects (formulate, represent, and solve the problems) are hierarchy in nature since every problem-solving begin with problem formulation, then representation mediates the students to prepare strategies and solve the problem.

\footnotetext{
${ }^{2}$ Uwong is defined as a person or pawn.
} 
Table 2. The indicators of strategic competence

\begin{tabular}{|c|c|c|}
\hline Strategic competence & Indicators & Coding \\
\hline Formulate the problems & $\begin{array}{l}\text { 1. Students can understand the situation or context } \\
\text { of the given problem } \\
\text { 2. Students can find key information and ignore } \\
\text { irrelevant ones of a problem } \\
\text { 3. Students can present mathematical problems in } \\
\text { various forms }\end{array}$ & M1 \\
\hline Represent the problems & $\begin{array}{l}\text { 1. Students can choose the presentation that is } \\
\text { suitable to help to solve the problem } \\
\text { 2. Students find mathematical relationships that } \\
\text { exist in a problem }\end{array}$ & M2 \\
\hline Solve the problems & $\begin{array}{l}\text { 1. Students can choose and develop effective } \\
\text { methods of problems solving } \\
\text { 2. Students can find solutions to the given } \\
\text { problems }\end{array}$ & M3 \\
\hline
\end{tabular}

\section{The implementation in classroom learning}

At this stage, we acted as a teacher to teach 20 seventh-grade students using the designed learning activities in two lessons. Table 3 was used to categorize students' strategic competence based on the results of the test. To analyse students' strategic competence based on the test results, we link Table 2 and Table 3 using a holistic assessment rubric. Student's answer which fulfilled one indicator was scored 4 , then the maximum score with 7 indicators was 28 . The answer that did not meet the indicator is scored 0. For the purpose of analysis, students who meet the three aspects of strategic competence or all seven indicators are coded KSM. The students who could fulfil several indicators are coded TSM. For example, if a student meets the first aspect, which consists of two indicators but unable to fulfil the other two aspects (five indicators), then he/she is included as TSM.

Table 3. Level of students' strategic competence

\begin{tabular}{cc}
\hline Student scores & Level of strategic competence \\
\hline $24-31$ & Very good \\
$16-23$ & Good \\
$8-15$ & Enough \\
$0-7$ & Less \\
\hline
\end{tabular}

\section{Findings and Discussion}

In this section, we firstly provide a description of the das-dasan game and the highlight of students' works in the group. Afterwards, we present students' achievement on strategic competence, referring to the results of the test, following by a discussion of this study.

\section{Das-dasan game}

The results of direct observation and interviews resulted in the following basics game description. The game of das-dasan is a traditional game in the kingdom of East Java, played in pairs to train the sharpness of thinking and set the strategy for the war. The das-dasan game has 32 uwong-uwongan consisting of 16 uwong from small pebbles and 16 uwong from large rocks. The rules in das-dasan games are as follows. 
1. Two players play the set of das-dasan

2. Before the game starts, the player first arranges the uwong-uwongan right at the intersection line of the game arena.

3. The player determines who has the right to run the uwong first in a suit.

4. Players run alternately uwong while setting strategies to be able to eat the opponent's uwong.

5. If a player forgets not to eat the opponent's uwong when given the bait, then it is said to be das so that the opponent has the right to take three uwong as he wishes (which needs to be considered when taking three uwong, namely by thinking of a strategy so that he can eat more uwong).

6. If uwong from one of the players can enter the opponent's triangle arena and walk around the stadium three times, then uwong can become king and can walk, jump away, and eat the opponent's uwong as desired.

7. Uwong can become king automatically if only one left.

8. Players are said to win if they can eat up the opponent's uwong.

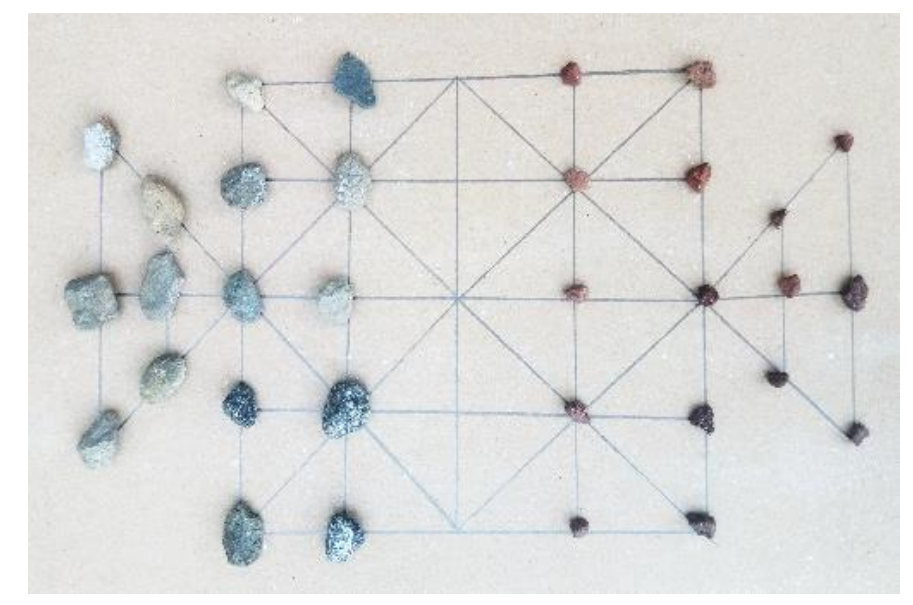

Figure 1. The arena of das-dasan and uwong

The linkage of das-dasan games with rectangle and triangle topic can be seen in the arena of das-dasan games presented in Figure 1. In the park of das-dasan games, several lines form a rectangular and triangular shape. Uwong, which is arranged in the arena of das-dasan games when followed by connecting one uwong with another uwong, can also form rectangular and triangular illustrations. The purpose of the game itself, which is to train one's sharpness of thought, closely relate to the objectives of learning mathematics: Promote students' strategic competence.

\section{Mathematics learning with das-dasan games}

Before the das-dasan game begins, students make suits (Figure 2). It allows the player who wins the suit to start the das-dasan game. Figure 3 shows students made observations on the game and exchange ideas to answer the task in the worksheet. 


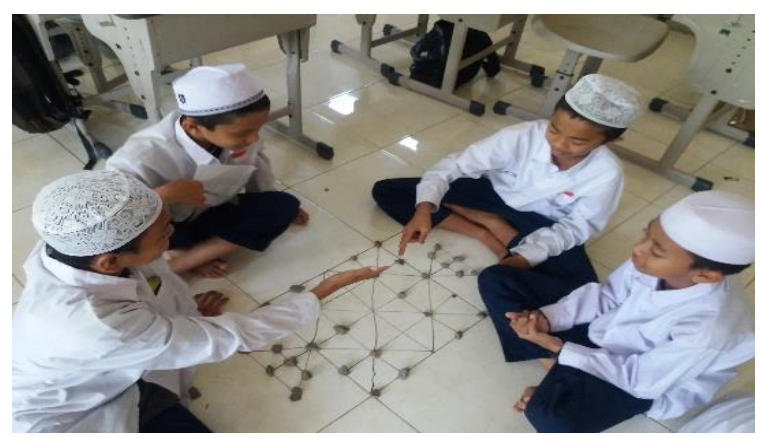

Figure 2. Students do a suit

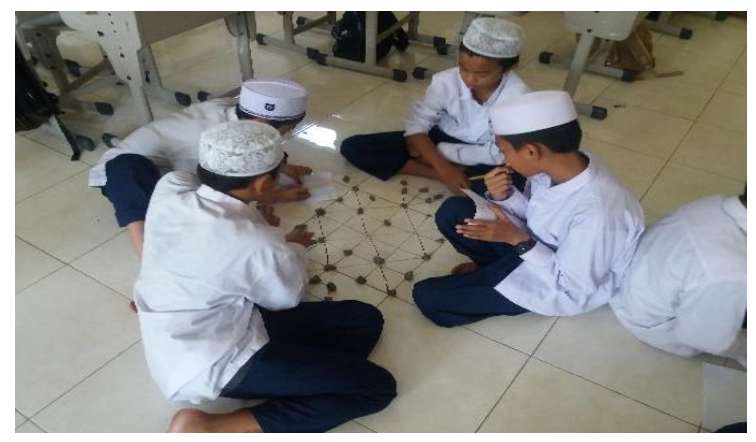

Figure 3. Students discuss the worksheet

Figure 4 and Figure 5 shows one of the group works in identifying and determining rectangles and triangles. The first step taken by the group to find rectangles is to connect the intersection points of lines from one location to another. It was found several rectangles that could be formed by joining several points. The group determined the triangles by observing the uwong that is being carried out and linking the lines on the das-dasan game arena to form triangular patterns. The results of the triangles and rectangles vary, which indicate that das-dasan game promotes students' learning on the topic.
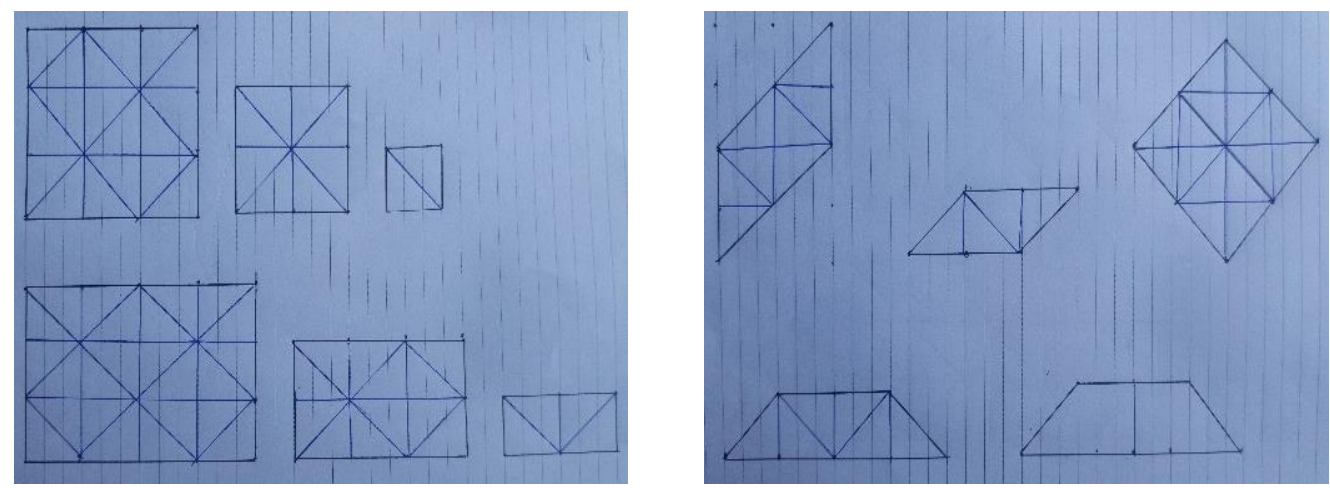

Figure 4. Rectangles in the das-dasan game arena 


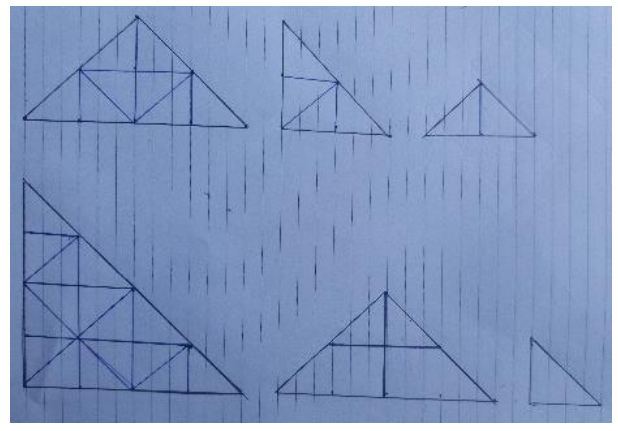

Figure 5. Triangles in the das-dasan game arena

\section{Students' mathematical strategic competence}

The competence was measured using a test after two lessons with das-dasan games. Table 4 shows students' scores on the test. There are 15 students (coded as KSM) who achieved all indicators. Meanwhile, 5 students (coded as TSM) fulfilled M1 (formulating the problem) but had not fully completed M2 (representing the problem) and M3 (solving the problem).

Table 4. Students' score in the test

\begin{tabular}{cccc}
\hline Interval & Frequency & Percentage (\%) & Category \\
\hline $24-31$ & 15 & 75 & Very good \\
$16-23$ & 5 & 25 & Good \\
$8-15$ & 0 & 0 & Enough \\
$0-7$ & 0 & 0 & Less \\
Total & 20 & 100 & \\
Average & 25,5 & Very good & \\
\hline
\end{tabular}

In Figure 6, KSM student correctly formulated the problem (M1). He understood the given problem and found the base and height of the plane by adding up the known ranges of the $7 \mathrm{~cm}$ square. Also, he represented the problem (M2) by drawing a parallelogram and its size. Next, students solve the problem (M3) by using the formula for the area of the parallelogram and find the correct result.

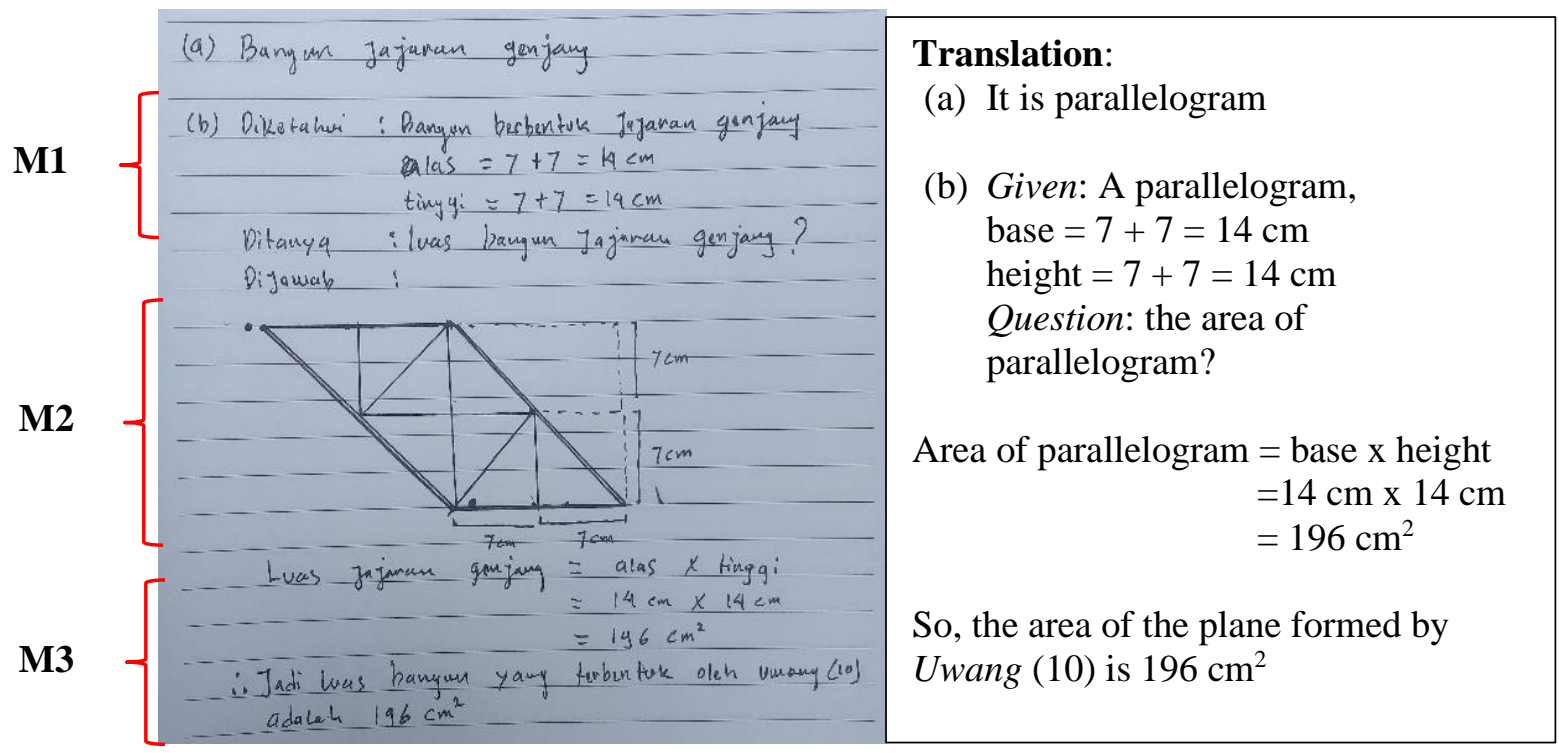

Figure 6. One of the KSM students' answer to the point (a) and (b) of the test 
In Figure 7, a TSM student correctly formulated the problem (M1), which included three indicators: understanding the context of the problem, determining appropriate, and presenting the problem correctly. He found the base $14 \mathrm{~cm}$ long and $14 \mathrm{~cm}$ high but did not write down how to get the base and height. The student could not properly represent the problem (M2) as he drew a representation of the parallelogram that did not fit the arena of das-dasan game. Furthermore, he had not been able to choose and develop effective problem-solving methods due to the incomplete information about the unit of measurement and the area formula.

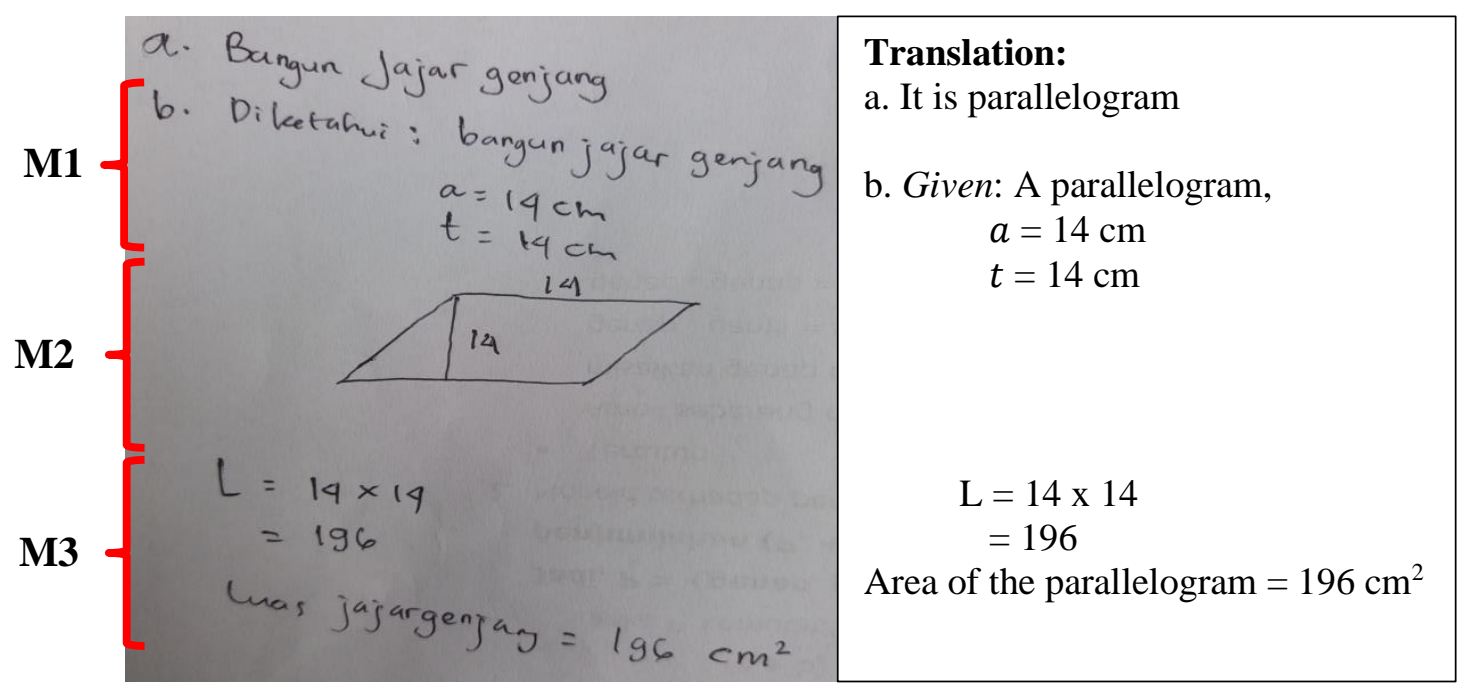

Figure 7. One of the TSM students' answer to the point (a) and (b) of the test

Figure 8 shows KSM (top) and TSM (bottom) student's answer to point (c) of the test. KSM student made a new quadrilateral by combining eight right triangles that form a parallelogram. Furthermore, from the mixed results of the eight triangles, an examination is conducted to ensure the rectangular shape found in the das-dasan game arena. This reveals that KSM students could formulate the problem, represent the problem by combining small triangles to form square, trapezoid and rectangle, and answer the question. The TSM student in made quadrilateral as KSM student did. However, when determining the third plane, he was less careful and thorough because he did not re-check the planes made so that the ways are not in the das-dasan game arena. He was only able to formulate and represent the problem but had not yet been able to solve the problem correctly.

The represented KSM student's work (Figure 6 and Figure 8) and our observation while he was working on the test unravel that the student was able to quickly formulated the problem by understanding the test questions first, then look for keywords to solve the problem by making uwong to connect from one point to another and small triangles to form the desired rectangles. Furthermore, he represented quadrilateral shapes and found the relationship between these shapes and the test questions to be completed. The student was precise in choosing the method of solving the problem. This finding, as the previous ones (Fouze \& Amit, 2018; Nkopodi \& Mosimege, 2009; Tatira et al., 2012), indicates that the use of cultural-based learning activities supports students construct mathematical knowledge. In addition, learning mathematics using traditional games allows students to be actively involved in learning. 


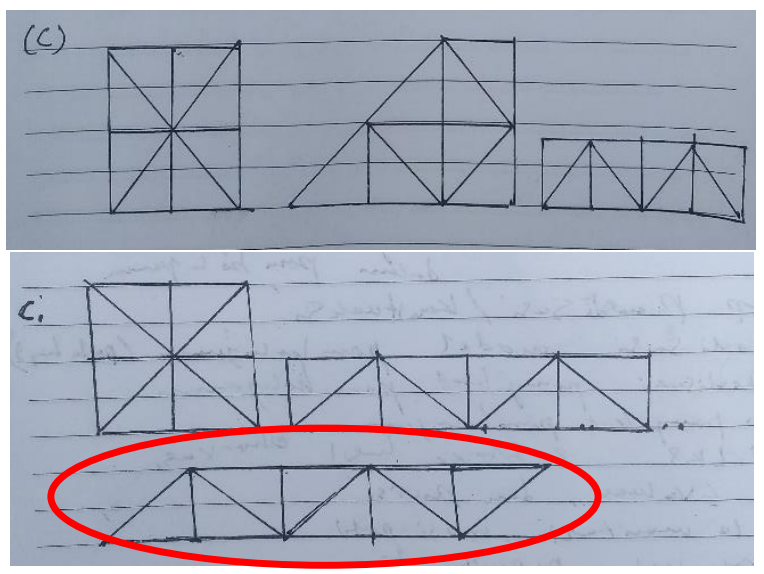

Figure 8. Two students' answers to point (c) of the test

On the other hand, the TSM student spent more time to understand the problem, improperly represented the problem, and had difficulty and was less precise in determining problem-solving strategies which affect the final result. We observed that the student experienced misconceptions shown in the results of drawing the ladder which is not in accordance with the estimation (length is more than height) and does not match the arena of the das-dasan game. Furthermore, he was inaccurate in writing the steps of problem-solving with words. Prior studies (Arifin \& Surya, 2019; Sigit, Utami, \& Prihatiningtyas, 2018) also show that students make errors in strategic competence since they are not able to understand the problem commands (concept errors), determine ideas to represent problems (principle errors), and be careful and precise in writing steps of problem-solving (procedural errors).

Despite the developed local game-based learning support the majority of students develop strategic competence, we argue that the two lessons are not representative enough to conclude the effectivity of the designed learning activities. In this case, it needs to be revised to address the students' need who have not achieved all indicators of strategic competence. Then, further empirical tryout involving more students and lessons is certainly required.

\section{Conclusion}

In this study, we developed local game-based mathematics learning to develop students' strategic competence in learning the topic of rectangle and triangle. This game can be done pratically since the tools and materials used are easily found in the school environment. The test shows that most of the students are able to formulate, represent, and solve triangle and rectangle problem embedding in the context of das-dasan game. However, several students are struggled with determining the mathematical ideas in the play of the game and choosing an appropriate strategy to solve the problem in the test which hamper their ability in solving the problem. We identified errors in determining the concept, principle, and procedure as the sources of the students' difficulty in accomplishing the last two parts of strategic competence.

\section{Acknowledgment}

The authors thank the two anonymous reviewers and the editors for their constructive comment used for revising the article. The inconsistencies or errors found in this article remain our own. 


\section{References}

Anderson-pence, K. L. (2015). Ethnomathematics: The role of culture in the teaching and learning of mathematics. Utah Mathematics Teacher, 3(2), 52-60.

Arifin, M. C., \& Surya, E. (2019). Analisis kemampuan representasi matematis siswa ditinjau dari kemampuan matematis siswa [Analyzing students' representation based on their mathematics ability]. Jurnal Pendidikan Matematika, 3(2), 1-10.

Bandeira, F. de A. (2017). Ethnomathematics three pedagogical proposals for primary education. ETD Educação Temática Digital, 19(3), 622-652. Doi: 10.20396/etd.v19i3.8648366

Brandt, A., \& Chernoff, E. J. (2015). The importance of ethnomathematics in the math class. Ohio Journal of School Mathematics, 2(71), 31-36.

Fouze, A. Q., \& Amit, M. (2018). Development of mathematical thinking through the integration of ethnomathematics Folklore game in math instruction. Eurasia Journal of Mathematics, Science and Technology Education, 14(2), 617-630. Doi: 10.12973/ejmste/80626

Gravemeijer, K., \& van Eerde, D. (2009). Design research as a means for building a knowledge base for teachers and teaching in mathematics education. The Elementary School Journal, 109(5), 510-524. Doi: $10.1086 / 596999$

Gravemeijer, K.P.E. (1994). Developing realistic mathematics education. Freudenthal Institute: Utrecht.

Helsa, Y., \& Hartono, Y. (2011). Designing reflection and symmetry learning by using math traditional dance in primary school. Journal on Mathematics Education,2(1), 79-94. Doi: 10.22342/jme.2.1.782.79-94

Ismail, M. R., \& Ismail, H. (2010). Exploring Malay-Islamic ethnomathematics: Al-Khatib's combinatoric theory in Àlam Al-Hussab and Raudah Al-Hussab. Procedia - Social and Behavioral Sciences, 8(5), 735-744. Doi: 10.1016/j.sbspro.2010.12.102

Jaelani, A., Putri, R. I. I., \& Hartono, Y. (2013). Students' strategies of measuring time using traditional gasing game in third grade of primary school. Journal on Mathematics Education, 4(1), 29-40. Doi: 10.22342/jme.4.1.560.29-40

Kilpatrick, J., Swafford, J., \& Findell, B. (Eds). (2001). Adding it up: Helping children learn mathematics. Washington, DC: National Academy Press.

Maryati., \& Pratiwi, W. (2019). Etnomatematika: Eksplorasi dalam tarian tradisional pada pembukaan asian games 2018. FIBONACCI, 5(1), 23-28. Doi: 10.24853/fbc.5.1.23-28

Nasrullah \& Zulkardi. (2011). Building counting by traditional game: Mathematics program for young children. Journal on Mathematics Education, 2(1), 41-54. Doi: 10.22342/jme.2.1.781.41-54

Nkopodi, N., \& Mosimege, M. (2009). Incorporating the indigenous game of Morabaraba in the learning of mathematics. South African Journal of Education, 29(3), 377-392. Doi: 10.15700/saje.v29n3a273

Nofrianto, A. (2015). Ethnomathematics: Mathematical concepts in Minangkabau traditional game. The International Conference on Mathematics, Science, Education and Technology (ICOMSET), 03(02), $1-4$.

Nursyahidah, F., Putri, R. I. I., \& Somakim. (2013). Supporting first-grade students' understanding of addition up to 20 using traditional game. Journal on Mathematics Education, 4(2), 212-223. Doi: 10.22342/jme.4.2.557.212-223

Palupi, E. L. W., \& Khabibah, S. (2018). Developing workshop module of realistic mathematics education: Follow-up workshop. IOP Conference Series: Materials Science and Engineering, 296(1). Doi: 10.1088/1757-899X/296/1/012006

Riberio, S. C. M. G., Palhares, P. M. B., \& Salinas, M. J. S. (2020). Ethnomathematical study on folk dances: Focusing on the choreography. Revemop, 2(3), 1-16. Doi: 10.33532/revemop.e202014

Risdiyanti, I., \& Prahmana, R. C. I. (2018). Etnomatematika: Eksplorasi dalam permainan tradisional Jawa [Ethnomathematics; Exploring Javanesse traditional games]. Journal of Medives, 2(1), 1-11. Doi: 10.31331/medives.v2i1.562

Rosa, M., \& Orey, D. C. (2011). Etnomatemática: Os aspectos culturais da Matematica (Ethnomathematics: The cultural aspects of mathematics). Revista Latinoamericana de Etnoatematica, 4(2), 32-54.

Rosa, M., \& Orey, D. C. (2017). Polysemic interactions of etnomathematics: An overview. ETD Educação Temática Digital, 19(3), 589-621. Doi: 10.20396/etd.v19i3.8648365

Saldanha, M.A., Kroetz, K., \& de Lara, I.C.M. (2016). Ethnomatematics: A possibility to deal with 
cultural diversity in classroom. Acta Scientiae, 18(2), 274-283.

Shandy, M. (2016). Realistic Mathematics Education (RME) untuk meningkatkan hasil belajar siswa sekolah dasar [RME to improve primary students' achievement in mathematics]. Jurnal Pendidikan Guru Sekolah Dasar, 1(1), 47-58. Doi: 10.17509/jpgsd.v1i1.9062

Sigit, J., Utami, C., \& Prihatiningtyas, N. C. (2018). Analisis kompetensi strategis matematis siswa pada sistem persamaan linier tiga variabel [Analyzing students' strategic competence on the topic of three variables linear equation system]. Variabel, 1(2), 60-65. Doi: 10.26737/var.v1i2.811

Sitorus, J., \& Masrayati. (2016). Students' creative thinking process stages: Implementation of Realistic Mathematics Education. Thinking Skills and Creativity, 22(3), 111-120. Doi: 10.1016/j.tsc.2016.09.007

Tatira, B., Mutambara, L. H. N., \& Chagwiza, C. J. (2012). The Balobedu cultural activities and plays pertinent to primary school mathematics learning. International Education Studies, 5(1), 78-85. Doi: 10.5539/ies.v5n1p78

Tereshkina, G. D., Merlina, N. I., Kartashova, S. A., Dyachkovskaya, M. D., \& Pyryrco, N. A. (2015). Ethnomathematics of indigenous peoples of the north. Mediterranean Journal of Social Sciences, 6(2), 233-240. Doi: 10.5901/mjss.2015.v6n2s3p233

Yuniati, S., \& Sari, A. (2018). Pengembangan modul matematika terintegrasi nilai-nilai keislaman melalui pendekatan Realistic Mathematics Education (RME) [Developing Islamic values-integrated mathematics module using RME]. Jurnal Analisa, 4(1), 1-9. Doi: 10.15575/ja.v4i1.1588

Zaenuri., Teguh, A. W. P. B., \& Dwidayati, N. (2017). Ethnomathematics exploration on the culture of Kudus city and its relation to junior high school geometry concept. International Journal of Education and Research, 5(9), 161-168. 